\title{
Author Correction: Long-term effects of mild traumatic brain injuries to oculomotor tracking performances and reaction times to simple environmental stimuli
}

\author{
Alessander Danna-Dos-Santos ${ }^{1,2}$, Sambit Mohapatra ${ }^{3}$, Maria Santos ${ }^{1}$ \& Adriana M. Degani ${ }^{1,2}$ \\ Correction to: Scientific Reports https://doi.org/10.1038/s41598-018-22825-5, published online 15 March 2018 \\ This Article contains typographical errors. In the Discussion section, all instances of \\ "Ettenhoffer and Bardy" \\ should read: \\ "Ettenhofer and Barry".
}

(i) Open Access This article is licensed under a Creative Commons Attribution 4.0 International (c) License, which permits use, sharing, adaptation, distribution and reproduction in any medium or format, as long as you give appropriate credit to the original author(s) and the source, provide a link to the Creative Commons license, and indicate if changes were made. The images or other third party material in this article are included in the article's Creative Commons license, unless indicated otherwise in a credit line to the material. If material is not included in the article's Creative Commons license and your intended use is not permitted by statutory regulation or exceeds the permitted use, you will need to obtain permission directly from the copyright holder. To view a copy of this license, visit http://creativecommons.org/licenses/by/4.0/.

(C) The Author(s) 2018

\footnotetext{
${ }^{1}$ Dr. Charles T Leonard Motor Control Laboratory, University of Montana, Missoula, MT, USA. ${ }^{2}$ Neural Injury Center, University of Montana, Missoula, MT, USA. ${ }^{3}$ Department of Rehabilitation \& Movement Sciences, University of Vermont, Burlington, VT, USA. Correspondence and requests for materials should be addressed to A.D.-D.-S. (email: alex.santos@umontana.edu)
} 